\title{
Rb-Sr geochronology of the Hikami granite, Kitakami mountains, Japan
}

\author{
Ken SHIBATA \\ Geological Survey of Japan \\ 135 Hisamoto, Takatsu-ku, Kawasaki 213, Japan
}

(Received December 16, 1974)

\begin{abstract}
Whole-rock samples of the Hikami granite from the southern Kitakami mountains in Northeast Japan give a Rb-Sr age of $339 \pm 12$ m.y with an initial ${ }^{87} \mathrm{Sr} /{ }^{86} \mathrm{Sr}$ ratio of $0.7079 \pm 0.0003$, indicating that the granite intruded in the late Devonian to early Carboniferous time. A slightly high initial ${ }^{87} \mathrm{Sr} /{ }^{86} \mathrm{Sr}$ ratio for the Hikami granite suggests that the granite assimilated some amount of older crust. The Tsubonosawa gneiss, which is contained in the Hikami granite as xenolithic masses, gives an isochron age of $334 \mathrm{~m}$.y with an initial ${ }^{87} \mathrm{Sr} /{ }^{86} \mathrm{Sr}$ ratio of 0.7129 . The results show that the $\mathrm{Sr}$ isotopic homogenization occurred among the whole masses of the gneiss at the time of granite intrusion. A higher initial ${ }^{87} \mathrm{Sr} /{ }^{86} \mathrm{Sr}$ ratio suggests that the gneiss originated in the Precambrian time.

Granite boulders from the Devonian Ono formation do not define any isochron, whereas the sandstone from the Silurian Kawauchi formation gives an apparent age of 264 m.y. The whole-rock systems of boulders and sandstone may have remained open with respect to $\mathrm{Rb}$ and $\mathrm{Sr}$, probably because of their involvement in sedimentary process.

The $\mathrm{Rb}-\mathrm{Sr}$ isotopic data for the Cretaceous Tono and Kesengawa granites confirm the evidence that almost all igneous rocks in Northeast Japan, irrespective of age, have low initial ${ }^{87} \mathrm{Sr} /{ }^{86} \mathrm{Sr}$ ratios, reflecting a distinctive nature of crust in Northeast Japan.
\end{abstract}

\section{INTRODUCTION}

The Hikami granite in the southern Kitakami mountains is one of older granites in Japan. It is characterized by its close relation to the Siluro-Devonian formations, by xenolithic inclusion of gneissose rocks, and by extensive alteration and mylonitization.

The age of the Hikami granite has been much discussed but not yet clearly defined, because of the complicated field relation between the granite and the surrounding rocks. Nevertheless, the age of intrusion was generally assumed to be Permian or younger. K-Ar ages of minerals for the Hikami granite are very discordant probably owing to the thermal effect of adjacent Cretaceous granite. On the basis of $\mathrm{K}$-Ar dating for hornblendes, however, the writer inferred that the Hikami granite 
was emplaced in late Devonian to early Carboniferous (ShibATA, 1973). Recently, Murata et al. (1974) made a detailed study on the relationship between the Hikami granite and the surrounding Siluro-Devonian formations, and concluded that the granite, at leașt a part of it, constitutes the pre-Silurian basement.

In order to solve the age problem of the Hikami granite, the writer carried out $\mathrm{Rb}-\mathrm{Sr}$ age determinations on the granite and related rocks mainly by the whole-rock method, and here presents the results and discusses a detailed geochronology of these rocks.

\section{Geological Setting}

The Hikami granite is exposed in an oval-shaped area measuring approximately

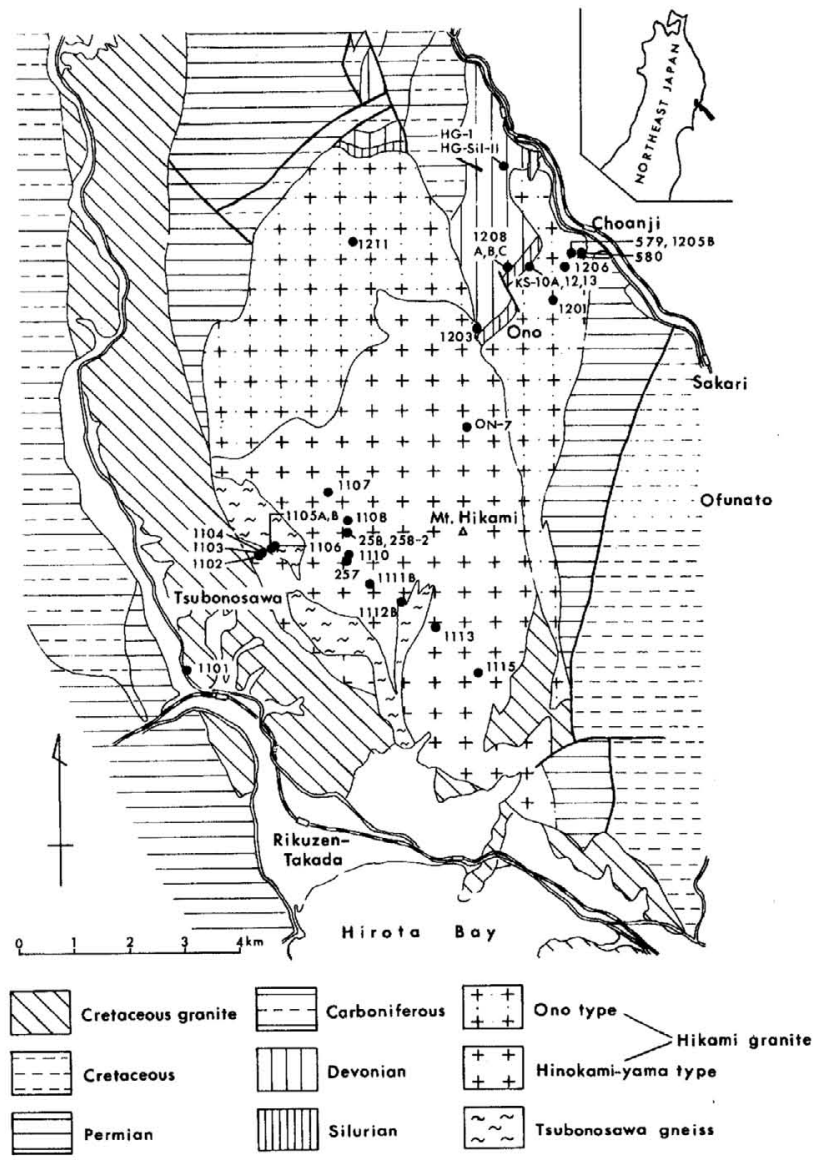

Fig.1. Geological map of the Hikami granite and surrounding area showing sample localities. The map is slightly modified from ISHII et al. (1960). 
$14 \mathrm{~km}$ north-south and $7 \mathrm{~km}$ east-west, between Ofunato and Rikuzen-takada Cities (Fig. 1). The granite is named after Mt. Hikami, which is the highest peak in this area and situated about $5 \mathrm{~km}$ west of Ofunato City.

The Hikami granite has been studied by many workers because of its characteristic nature (W ATANABE, 1950; SuzUKI, 1952, 1958; KANO, 1954, 1955; Shibata and OKada, 1955; Ishi et al., 1960; Murata et al., 1974). According to the detailed petrographic study by IsHI et al. (1960), the Hikami granite is divided into the Hinokami-yama type and the Ono type. The Hinokami-yama type occupies about two-thirds of the Hikami granite in area, and is exposed in the central, western and southern parts. The rock shows generally a gneissose structure and consists mainly of granodiorite or tonalite. In its western part Hinokami-yama type rocks contain distinctive metamorphic rocks, called the Tsubonosawa gneiss, as large xenolithic masses (SuzuKI, 1956). The metamorphic rocks are composed mostly of biotite gneiss with a small amount of amphibolite, and are characterized by the local occurrence of andalusite and sillimanite. The western and southern margin of the Hinokamiyama type is bounded and contact-metamorphosed by the Cretaceous Kesengawa granite. The thermal effect of this granite extends at least $4 \mathrm{~km}$ from the boundary, resulting in recrystallization of biotites in the Hikami granite to rather fresh fine aggregate.

The Ono type is exposed in the eastern and northern parts and is mostly of nonschistose granodiorite. Mylonitization is remarkable for this type, particularly in the eastern part. Specially mentioned is the granite with chequer albite that was recently found by us in the vicinity of Ono (Nozawa, Yoshida, Katada and Shibata, unpublished data); a similar rock type is described by Murata et al. (1974) for granite boulders in the Ono formation.

Both types of the Hikami granite have a protoclastic texture and are more or less altered; chloritization of biotite and albitization of plagioclase are recognized. The Ono type rocks are more severely altered than the Hinokami-yama type rocks, and are supposed to have been formed under hydrous and low-temperature conditions (IsHI et al., 1960).

The relationship between the Hikami granite and the surrounding Paleozoic formations has been very much controversial. Although the granite is in direct contact with Silurian to Permian formations in many localities, these are almost free from contact-metamorphism. Based on the structural harmony between the granite and the surrounding Paleozoic formations, Kano (1955) supposed that the Hikami granite intruded in the middle Permian time. IsHI et al. (1960) observed the contact relationship in several localities, and interpreted that the time of intrusion for the Ono type is post-Permian. Oкuвo (1950), Onuki (1969), and Minato et al. (1973a, b) considered that the Hikami granite intruded Siluro-Devonian formations. Our recent investigation also confirms that the Hikami granite intruded a Devonian forma- 
tion (Nozawa et al., 1975). On the contrary, Murata et al. (1974) found an outcrop where arkose sandstone belonging to the base of the Silurian Kawauchi formation overlies the Ono type granite with a minor fault. From the mineralogical similarity between the granite and the sandstone, they concluded that the Hikami granite is the pre-Silurian basement.

Another important evidence related to the Hikami granite is the occurrence of granitic clasts in the basal part of the newly defined Ono formation (Murata et al., 1974). This horizon was formerly included in the Silurian Takainari formation (OKUBO, 1950; ONUKI, 1969). However, these granitic rocks have been interpreted to be protoclastic dikes of granite (ONUKI, 1969; Minato et al., 1973b). MiKami (1971), on the other hand, considered these granitic rocks as of clastic origin. On the basis of the detailed study of the granitic clasts, Murata et al. (1974) interpreted also that these rocks are clastic sediments, and that the clasts are divided into two types: trondhjemitic rock with chequer albite and normal granitic rock; the latter corresponding to the Ono type of the Hikami granite petrographically. These facts are emphasized by MuRATA et al. (1974) as another evidence for the pre-Silurian age of the Hikami granite.

Radiometric dating of the Hikami granite was first done by KAWANO and UEDA (1964), giving K-Ar ages of $222 \mathrm{~m} . \mathrm{y}$ on orthoclase and $164 \mathrm{~m} . \mathrm{y}$ on biotite. These results were supposed to be younger than the age of intrusion owing to the thermal effect of the Cretaceous granite. The writer also obtained discordant K-Ar mineral ages for the Hikami granite; 354 and $315 \mathrm{~m}$.y on hornblende and 114, 115 and $190 \mathrm{~m} . \mathrm{y}$ on biotite and interpreted that the hornblende age of $354 \mathrm{~m}$.y is probably close to the time of granite intrusion (ShiBATA, 1973). The younger biotite ages are equal to an age of $112 \mathrm{~m} . \mathrm{y}$ for the Kesengawa granite (KAWANO and UEDA, 1965), indicating that biotite from some part of the Hikami granite has been completely rejuvenated with respect to K-Ar age. Further K-Ar analyses (Murata et al., 1974; Shibata and UCHIUmI, 1975) confirm the discordance of K-Ar ages of the Hikami granite.

\section{Analytical Procedures}

Sample localities of the Hikami granite and related rocks used for the $\mathrm{Rb}-\mathrm{Sr}$ analyses are shown in Fig. 1 and also given by latitude and longitude in Table 1. About half of the samples were collected from rather fresh outcrops along a newly constructed road surrounding Mt. Hikami. As $\mathrm{Rb} / \mathrm{Sr}$ ratios of the granite are generally low and not very favorable for the whole-rock isochron study, as many as 21 whole-rock samples of the Hikami granite were analyzed. In addition, wholerock samples of the Tsubonosawa gneiss, granite boulders and sandstone from the Siluro-Devonian formations, and the Cretaceous granite were analyzed. At least $1 \mathrm{~kg}$ of a rock was crushed and carefully split to obtain a representative whole-rock sample. 


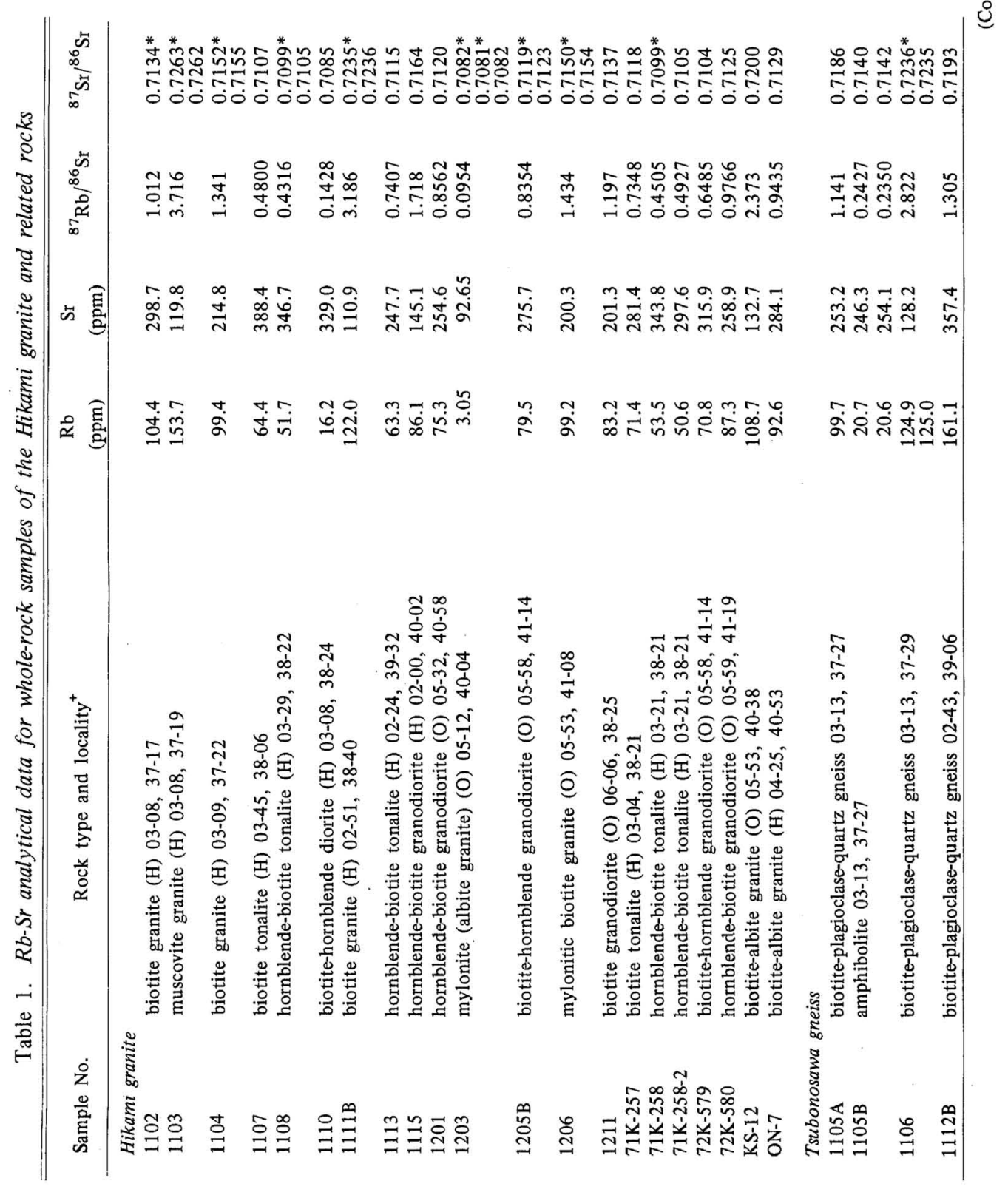




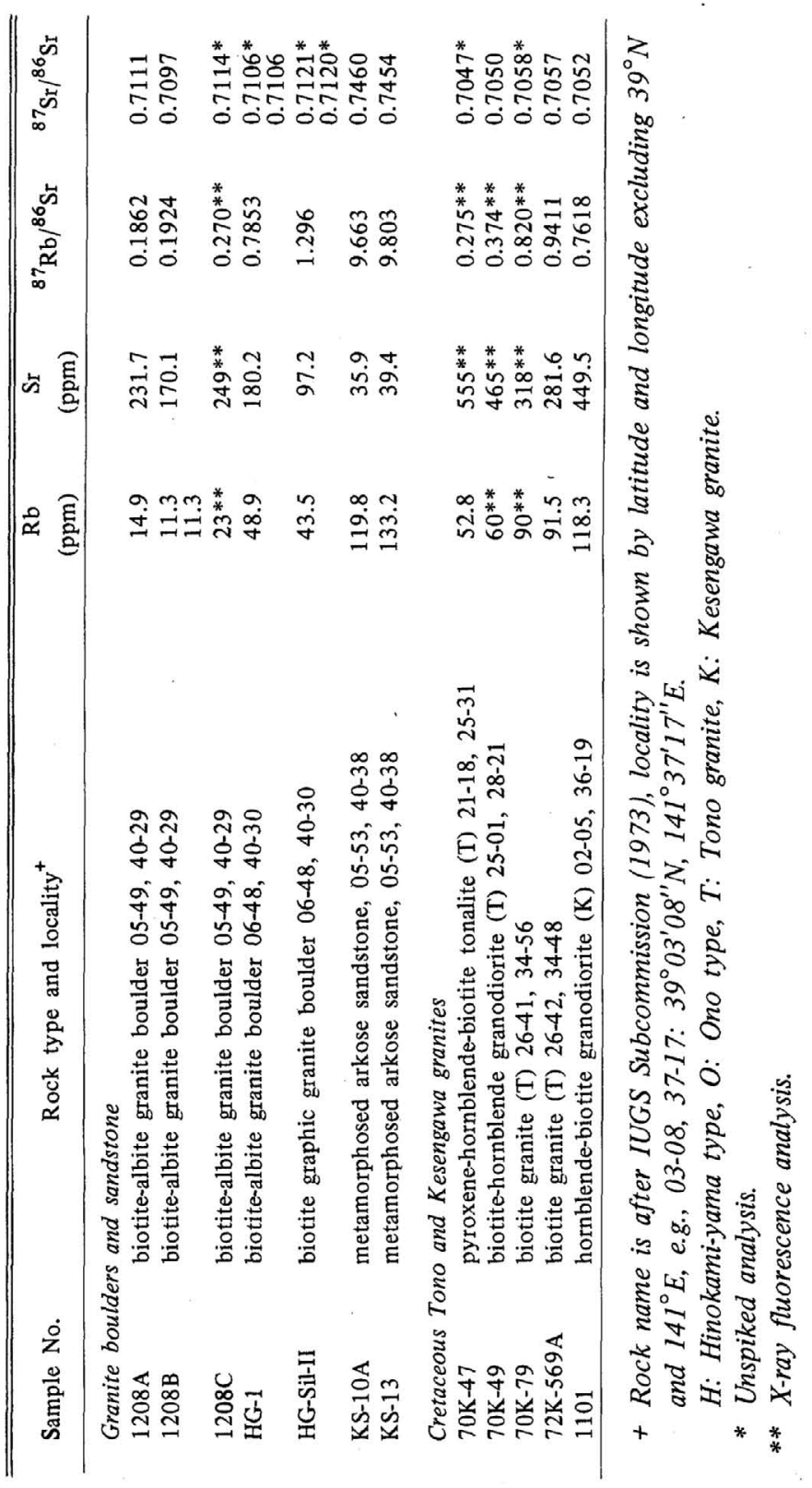


$\mathrm{Rb}$ and $\mathrm{Sr}$ concentrations were measured by isotope dilution using ${ }^{87} \mathrm{Rb}$ and ${ }^{84} \mathrm{Sr}$ spikes, and ${ }^{87} \mathrm{Sr} /{ }^{86} \mathrm{Sr}$ ratios were calculated from the spiked runs. Further, ${ }^{87} \mathrm{Sr} /{ }^{86} \mathrm{Sr}$ ratios were separately determined from unspiked runs for about half of the samples, and average ${ }^{87} \mathrm{Sr} /{ }^{86} \mathrm{Sr}$ ratios were used for the isochron calculation. The mass spectrometric analyses were done on the JEOL-05RB mass spectrometer with a $90^{\circ}-$ $30 \mathrm{~cm}$ radius analyzer. Triple filaments were used and samples were loaded on the side filaments as $\mathrm{Rb}_{2} \mathrm{SO}_{4}$ or $\mathrm{Sr}\left(\mathrm{NO}_{3}\right)_{2}$. Ion currents were detected with an electron multiplier, output of which was amplified by a vibrating reed electrometer, recorded on a digital voltmeter and punched on paper tape. Data reduction was done by a computer.

All ${ }^{87} \mathrm{Sr} /{ }^{86} \mathrm{Sr}$ ratios were normalized to ${ }^{87} \mathrm{Sr} /{ }^{86} \mathrm{Sr}$ ratio of 0.1194 . The standard deviation for the average of $10 \sim 20$ peak ratios is mostly $0.05 \sim 0.12 \%$. The analyses of the Eimer and Amend $\mathrm{Sr}$ standard made during the course of this study range in ${ }^{87} \mathrm{Sr} /{ }^{86} \mathrm{Sr}$ ratio from 0.70803 to 0.70872 with an average of $0.70845 \pm$ $0.00022(1 \sigma)$. The uncertainty in $\mathrm{Rb}$ and $\mathrm{Sr}$ concentrations is estimated to be within $\pm 2 \%$. For a few samples with low $\mathrm{Rb} / \mathrm{Sr}$ ratios, $\mathrm{Rb}$ and $\mathrm{Sr}$ concentrations were measured by X-ray fluorescence analysis. In this case the analytical uncertainty for the concentration is $\pm 10 \%$ or more, while that for the $\mathrm{Rb} / \mathrm{Sr}$ ratio is better and is estimated to be within $\pm 5 \%$.

Isochrons were calculated by the least-square method of YORK (1966) taking account of uncertainties of $\pm 3 \%$ in ${ }^{87} \mathrm{Rb} /{ }^{86} \mathrm{Sr}$ ratios and $\pm 0.15 \%$ in ${ }^{87} \mathrm{Sr} /{ }^{86} \mathrm{Sr}$ ratios, and the errors are at the $95 \%$ confidence level. All ages given in this paper were calculated using ${ }^{87} \mathrm{Rb}$ decay constant of $1.47 \times 10^{-11} / \mathrm{y}$. In addition to the wholerock analyses, $\mathrm{Rb}-\mathrm{Sr}$ analyses were made on mica from two rock samples of the Hikami granite.

\section{Results AND Discussion}

$\mathrm{Rb}-\mathrm{Sr}$ analytical data for whole-rock samples of the Hikami granite and related rocks are given in Table 1, and those for mica separated from the granite are given in Table 2 together with the mica-whole rock isochron ages.

Table 2. Rb-Sr analytical data and ages of mica from the Hikami granite

\begin{tabular}{lllcccl} 
Sample No. & Mineral & $\begin{array}{c}\mathrm{Rb} \\
(\mathrm{ppm})\end{array}$ & $\begin{array}{c}\mathrm{Sr} \\
(\mathrm{ppm})\end{array}$ & ${ }^{87} \mathrm{Rb} /{ }^{86} \mathrm{Sr}$ & ${ }^{87} \mathrm{Sr} /{ }^{86} \mathrm{Sr}$ & $\begin{array}{l}\text { Age* } \\
(\mathrm{m} . \mathrm{y})\end{array}$ \\
\hline 1103 & muscovite & 548.2 & 22.4 & 70.84 & 0.8335 & 109 \\
$71 \mathrm{~K}-258$ & biotite & 333.5 & 25.7 & 37.58 & 0.7716 & 113 \\
\hline
\end{tabular}

* Age is calculated from the mica-whole rock isochron.

Hikami granite Whole-rock data for 21 samples; 13 Hinokami-yama type and 8 Ono type rocks, are plotted in Fig. 2. They define an isochron of $339 \pm 12 \mathrm{~m}$.y 
with an initial ${ }^{87} \mathrm{Sr} /{ }^{86} \mathrm{Sr}$ ratio of $0.7079 \pm 0.0003$. All points for both the Hinokamiyama and Ono types lie on the isochron within the experimental error. The results indicate that the isochron is highly reliable, and that both types of the Hikami granite

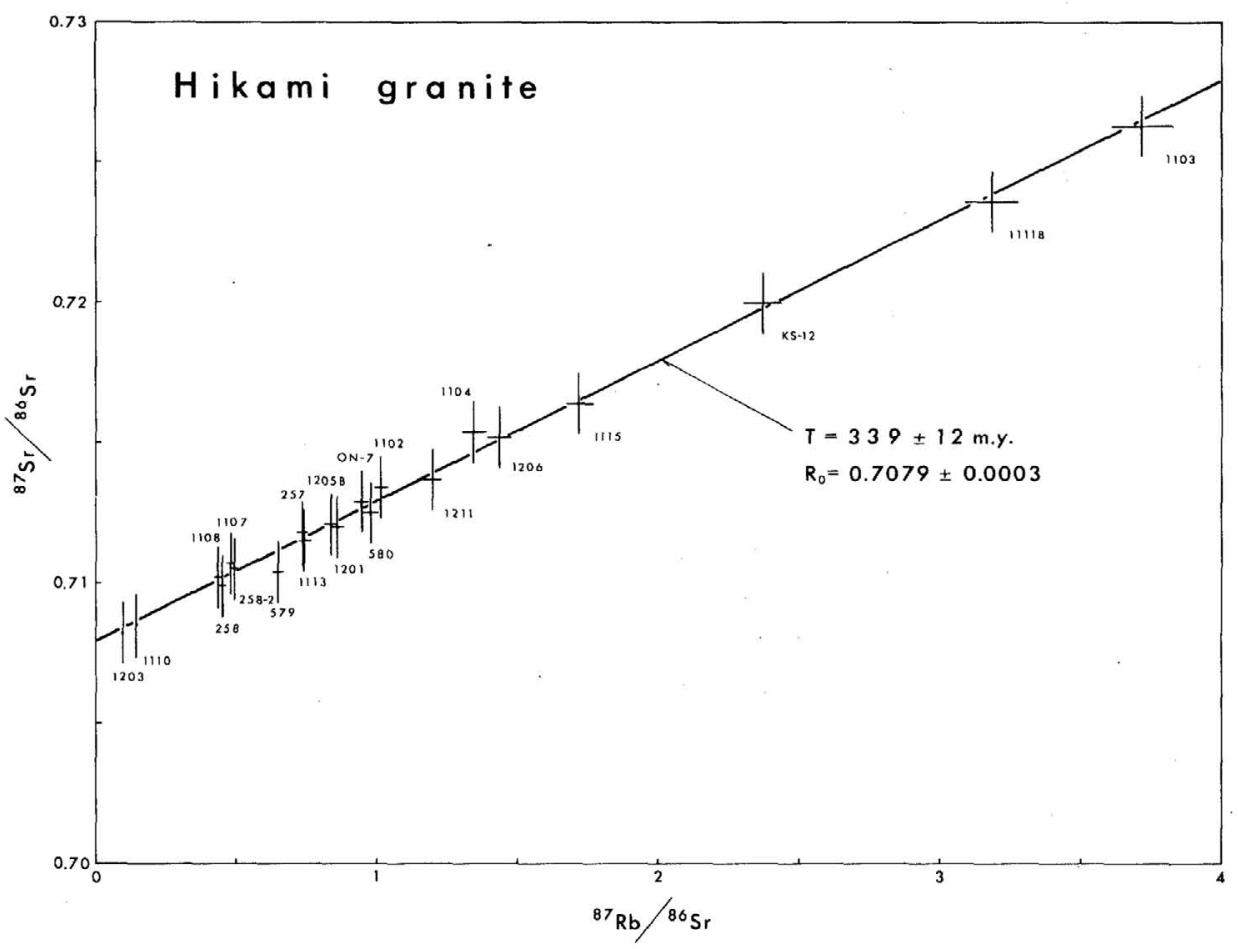

Fig.2. $R b$-Sr whole-rock isochron for the Hikami granite.

have the same age and initial ratio. $\mathrm{Rb}$ and $\mathrm{Sr}$ concentrations and $\mathrm{Rb} / \mathrm{Sr}$ ratios are not very distinguishable between the two types, although higher $\mathrm{Rb} / \mathrm{Sr}$ ratios are found in the Hinokami-yama type. Even the samples near the contact of the Cretaceous Kesengawa granite (Samples 1102, 1103, 1104) have not been disturbed with respect to $\mathrm{Rb}$ and $\mathrm{Sr}$. Sample 1110 is a small basic xenolith with dioritic composition in the Hikami granite. It has a low $\mathrm{Rb} / \mathrm{Sr}$ ratio but is on the isochron, indicating that the rock has been completely homogenized isotopically with the Hikami granite. Sample 1203 is the mylonitized albite granite that was recently found at an outcrop about $1 \mathrm{~km}$ west of Ono, and is characterized by chequer albite. A similar rock was previously found among granite boulders in the Ono formation (MURATA et al., 1974). Sample 1203 has the lowest $\mathrm{Rb}$ concentration and $\mathrm{Rb} / \mathrm{Sr}$ ratio among the 
rocks analyzed, but its data-point lies on the $339 \mathrm{~m}$.y isochron, clearly indicating that the rock is a part of the Hikami granite. Sample 1206 is a granite collected from the locality where the Cretaceous granite is supposed to be exposed according to the map of IsHil et al. (1960). The data-point for this rock is also on the $339 \mathrm{~m}$.y isochron; therefore the rock is not Cretaceous in age.

The whole-rock isochron age of $339 \mathrm{~m}$.y for the Hikami granite may be interpreted to indicate either the time of emplacement of the Hikami granite or that of high-grade metamorphism after the emplacement. However, no geological and petrographical evidence for the extensive metamorphism is observed in the granite as well as in surrounding rocks. This fact, together with the highly correlated isochron defined by many samples from the wide area of the granite body, leads to the conclusion that the $339 \mathrm{~m}$.y age represents the time of emplacement for the Hikami granite. A slight but significant difference between the isochron age and the hornblende age of $354 \mathrm{~m} . y$ (Shibata, 1973) can be explained in terms of the ${ }^{87} \mathrm{Rb}$ decay constant. If $\lambda=1.39 \times 10^{-11} / \mathrm{y}$ is used, the isochron age is increased to $359 \mathrm{~m} . \mathrm{y}$, thus the concordance of both ages further confirms that the Hikami granite was formed in late Devonian to early Carboniferous. The problem on the initial ${ }^{87} \mathrm{Sr} /{ }^{86} \mathrm{Sr}$ ratio of the Hikami granite will be discussed later.

The $\mathrm{Rb}-\mathrm{Sr}$ ages of mica separated from the Hikami granite are given in Table 2. The isochron ages of $109 \mathrm{~m}$.y for muscovite and $113 \mathrm{~m}$.y for biotite are equal to K-Ar ages of 107 and $114 \mathrm{~m} . y$, respectively (Shibata, 1973; Shibata and Uchiumi, 1975); all indicating the complete rejuvenation by the Kesengawa granite.

The age of 339 m.y on the Hikami granite is roughly correlated with the ages of some older granitic rocks in Southwest Japan. In the Kurosegawa tectonic zone the Yatsushiro granite gives a Rb-Sr whole-rock age of $333 \mathrm{~m}$.y (NoHDA, 1973; recalculated by $\lambda=1.47 \times 10^{-11} / \mathrm{y}$ ), and Mitaki granite gives a biotite-whole rock age of 377 m.y (IsHIZAKA, 1972). The Dai granite in the Nagato tectonic zone gives a micawhole rock age of $372 \mathrm{~m}$.y (IsHIzAKA, 1974). All these rocks are similar in tectonic and petrographic features; they are exposed as rather small lenticular bodies within the tectonic zones, sheared and altered severely, and generally granodioritic to tonalitic in composition and depleted in $\mathrm{K}_{2} \mathrm{O}$. These features are also similar to those of the Hikami granite, although the Hikami granite is exposed in the much wider area. In Northeast Japan, some of the granitic rocks in the Abukuma mountains are supposed to have been emplaced about $350 \mathrm{~m}$.y ago (MARUYAMA, 1972). The abovementioned facts provide the definite evidence for the plutonism that took place in the middle Paleozoic time throughout the Japanese Islands.

Although it is not possible that the Hikami granite is the pre-Silurian basement in view of the present age results, the Hikami granite represents one of the middle Paleozoic plutonic rocks in the Japanese Islands, and must have been much related with the tectonic development of the southern Kitakami mountains. 
Tsubonosawa gneiss Four whole-rock samples are analyzed for $\mathrm{Rb}$-Sr study. Three of them lie on an isochron giving an age of $334 \pm 18 \mathrm{~m}$.y and an initial ${ }^{87} \mathrm{Sr} /{ }^{86} \mathrm{Sr}$ ratio of $0.7129 \pm 0.0003$ (Fig.3). Sample 1106 is below this isochron. This is a biotite gneiss, of which biotite makes up about $25 \%$. Probably owing to abundant biotite in this rock, the whole-rock system may have been opened at the time of the Cretaceous granite intrusion. It is noted that the isochron age of the Tsubonosawa gneiss is similar to that of the Hikami granite, whereas the initial ${ }^{87} \mathrm{Sr} /{ }^{86} \mathrm{Sr}$ ratio of the former is significantly higher than that of the latter. This might mean that the Tsubonosawa gneiss was formed at the same time as the granite intrusion. From the xenolithic feature of the Tsubonosawa gneiss, however, it is interpreted more probably that the $\mathrm{Sr}$ isotopic homogenization took place among the entire masses of the gneiss at the time of granite intrusion. Because of considerably large size of the gneiss, the mixing of the $\mathrm{Sr}$ isotopes between the gneiss and the granite may have hardly occurred, thus resulting in the higher ${ }^{87} \mathrm{Sr} /{ }^{86} \mathrm{Sr}$ ratio. If this is the case, the Tsubonosawa gneiss must be older than the Hikami granite. Assuming the average ${ }^{87} \mathrm{Rb} /{ }^{86} \mathrm{Sr}$ ratio of the Tsubonosawa gneiss to be 1.0 , which is nearly equal to that of the Hikami granite, it takes about $340 \mathrm{~m}$.y for the gneiss to be increased in the ${ }^{87} \mathrm{Sr} /{ }^{86} \mathrm{Sr}$ ratio by 0.0050 . It is therefore possible that the Tsubonosawa gneiss originated in the Precambrian time.

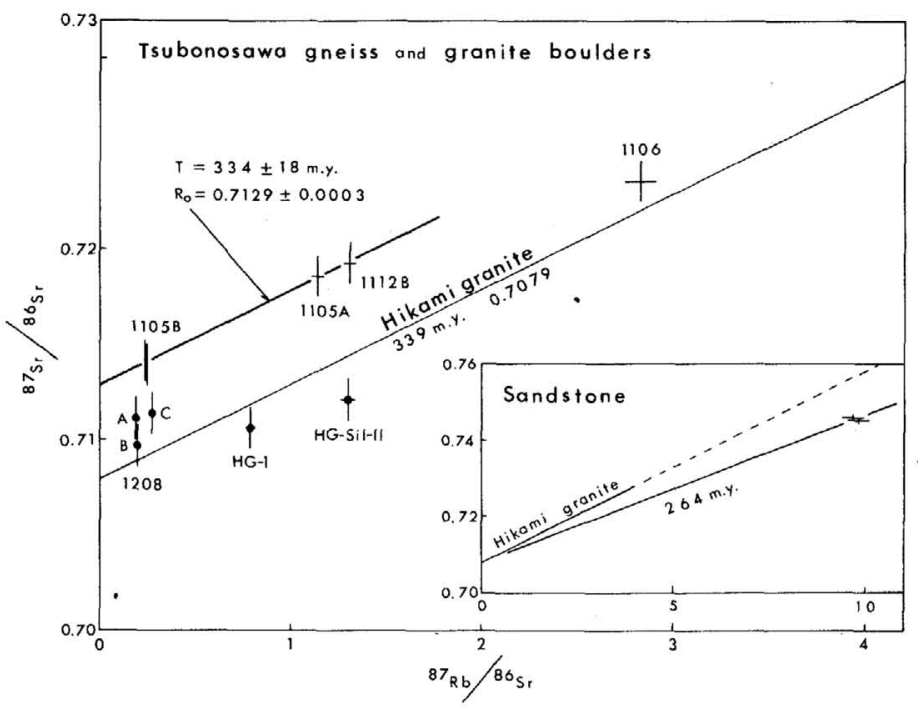

Fig.3. Rb-Sr isochron plot for whole-rock samples of the Tsubonosawa gneiss, granite boulders and sandstone. Data-point with solid circle represents granite boulder. 
Granite boulders and sandstone $\quad \mathrm{Rb}-\mathrm{Sr}$ analytical data for seven whole-rock samples of granite boulders and sandstone are given in Table 1 and plotted in Fig. 3. Samples $1208 \mathrm{~A}, \mathrm{~B}$ and $\mathrm{C}$ are granite boulders in the Ono formation collected from Sasanodaira west of Choanji, HG-1 is a sample from a large granite block at least $10 \mathrm{~m}$ across, and HG-Sil-II is a granite boulder, both from the Ono formation at Higuchizawa northwest of Choanji. Three samples from Sasanodaira and HG-1 are granitic in composition and characterized by chequer albite (Murata et al., 1974). These are similar to 1203 of the Hikami granite, and all low in Rb concentration.

As shown in Fig. 3 the data-points for five whole-rock samples of boulders do not define any meaningful isochron, but their ${ }^{87} \mathrm{Sr} /{ }^{86} \mathrm{Sr}$ ratios are rather similar despite different $\mathrm{Rb} / \mathrm{Sr}$ ratios. The results are inconsistent with the geological evidence that these boulders are Devonian or older in age, and hence they suggest that the rocks have remained open systems with respect to $\mathrm{Rb}$ and $\mathrm{Sr}$. It is, however, difficult to explain why the boulders have remained open while the Hikami granite has been a closed system, although it is probable that the granite boulders have been more susceptible to chemical and isotopic alteration as they were involved in a sedimentary process. Further study is needed to solve this problem.

Two whole-rock samples of sandstone collected from the base of the Silurian Kawauchi formation at Kusayamizawa near Sasanodaira are plotted in the inset of Fig. 3. They have exceptionally high $\mathrm{Rb} / \mathrm{Sr}$ ratios compared with those of the Hikami granite, and give an apparent $\mathrm{Rb}-\mathrm{Sr}$ age of $264 \mathrm{~m}$.y with an assumed initial ${ }^{87} \mathrm{Sr} /{ }^{86} \mathrm{Sr}$ ratio of 0.7079 . None of the Hikami granite and granite boulders have such a low $\mathrm{Sr}$ concentration and high $\mathrm{Rb} / \mathrm{Sr}$ ratio. The sandstone overlies the Ono type granite with a minor fault, the fact of which is considered by MuRata et al. (1974) as the evidence for the pre-Silurian age of the Hikami granite. However, the data-point for this granite (KS-12) is on the isochron of the Hikami granite as shown in Fig. 2, indicating that this rock is a part of the Hikami granite having the age of $339 \mathrm{~m} . \mathrm{y}$. It is therefore now evident that the relation between the granite and the overlying sandstone is not unconformity but is fault contact or intrusive. The sandstone seems to have been thermally metamorphosed because fine flakes of muscovites are observed around grain boundaries, and this might have been caused by the underlying granite. It is also quite clear that the sandstone is very much distinct from the underlying granite in petrochemical and $\mathrm{Sr}$ isotopic natures.

The age of $264 \mathrm{~m}$.y for the sandstone may not be considered to indicate any geological event, since the sandstone may have been an open system with respect to $\mathrm{Rb}$ and $\mathrm{Sr}$. However, the possibility that this is in fact an acidic igneous rock such as quartz-porphyry, and that the age indicates the time of intrusion or metamorphism, cannot be ruled out, when its low $\mathrm{Sr}$ concentration and high $\mathrm{Rb} / \mathrm{Sr}$ ratio are considered.

Initial ${ }^{87} \mathrm{Sr} /{ }^{86} \mathrm{Sr}$ ratio $\quad$ The initial ${ }^{87} \mathrm{Sr} /{ }^{86} \mathrm{Sr}$ ratio for the Hikami granite is $0.7079 \pm$ 
0.0003 (Fig. 2), and is only slightly higher than that for oceanic basalts $(0.702 \sim$ 0.706). It is therefore probable that the Hikami granite was not derived from reworked material of much older crust. In fact the largest volume fraction of granitic rocks have initial ${ }^{87} \mathrm{Sr} /{ }^{86} \mathrm{Sr}$ ratios of $0.707 \pm 0.001$ (FAURE and PowELL, 1972), hence the Hikami granite is not exceptional in this regard.

In order to discuss this problem further, $\mathrm{Rb}-\mathrm{Sr}$ analyses were made for the Cretaceous Tono and Kesengawa granites of the Kitakami mountains. The Tono granite is the largest among the Cretaceous granitic rocks in the Kitakami mountains, and is exposed north of the Hikami granite in an area about $35 \mathrm{~km}$ long and $20 \mathrm{~km}$ wide. The Rb-Sr data for four whole-rock samples from the Tono granite are given in Table 1 and plotted in Fig. 4. They define an isochron age of $108 \pm 39 \mathrm{~m}$.y with an initial ${ }^{87} \mathrm{Sr} /{ }^{86} \mathrm{Sr}$ ratio of $0.7043 \pm 0.0004$. A single data-point for a whole-rock sample (1101) of the Kesengawa granite is also on the isochron. The large error in age is due to low $\mathrm{Rb} / \mathrm{Sr}$ ratios of the Tono granite, and yet the age is essentially concordant with K-Ar ages of 110-122m.y for biotite from the Tono granite (Kawano and UEDA, 1965), indicating the time of emplacement for the granite. As seen in Fig. 4, however, the initial ratio of 0.7043 for the Tono granite is significantly lower than that for the Hikami granite. Moreover, some of granitic rocks in the Abukuma mountains, including those as old as $400 \mathrm{~m}$.y, have also low initial ratios of $0.7038 \sim$ 0.7055 (MaRUYAMA, 1972). In view of commonly low initial ${ }^{87} \mathrm{Sr} /{ }^{86} \mathrm{Sr}$ ratios of granitic rocks in Northeast Japan, the slightly higher initial ratio of the Hikami granite may be interpreted as anomalous for Northeast Japan. It is possible, therefore, that the Hikami granite assimilated some amount of older sialic material at the time of emplacement. This interpretation is supported by the evidence that the $\mathrm{Hi}$ kami granite contains xenolithic masses of the Tsubonosawa gneiss, the age of which is estimated geologically and geochronologically to be older than the granite.

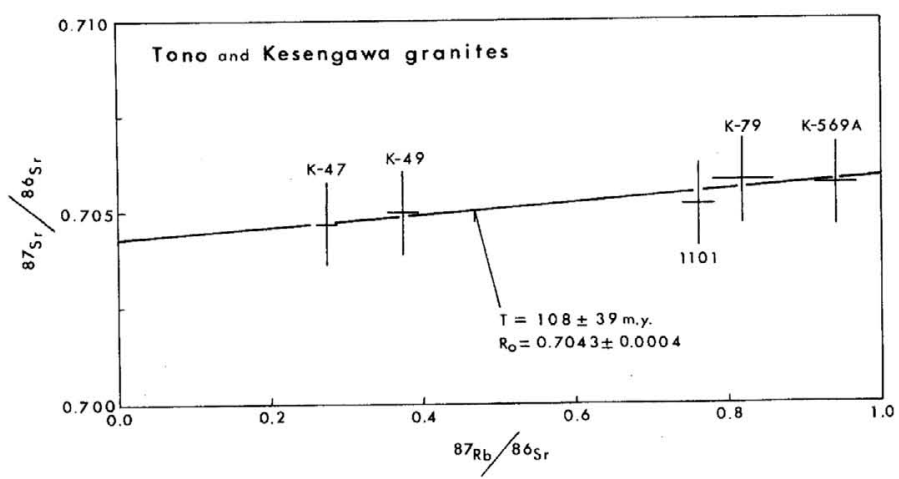

Fig.4. Rb-Sr isochron plot for whole-rock samples of the Cretaceous Tono and Kesengawa granites. Sample 1101 is excluded from the calculation of isochron age. 
Almost all Cenozoic volcanic rocks in Northeast Japan have low ${ }^{87} \mathrm{Sr} /{ }^{86} \mathrm{Sr}$ ratios ranging from 0.703 to 0.705 (KuRASAwA, 1972; SHUTO, 1974). Thus the low initial ${ }^{87} \mathrm{Sr} /{ }^{86} \mathrm{Sr}$ ratios of both plutonic and volcanic rocks, irrespective of age, are considered to be a characteristic feature of Northeast Japan, and indicate that these rocks have been derived from the deep source region without older crustal contamination. This makes a marked contrast to variable but generally high initial ${ }^{87} \mathrm{Sr} /{ }^{86} \mathrm{Sr}$ ratios of igneous rocks in Southwest Japan. Accordingly, it is suggested that the older crust of Northeast Japan is of smaller scale in size compared with that of Southwest Japan, and/or that mechanism of magma generation is different between Northeast and Southwest Japan. A thick layer with the velocity of $6 \mathrm{~km} / \mathrm{sec}$ in Northeast Japan (HASHIZUME et al., 1968) may possibly be composed largely of younger granitic rocks. In any case the older crust in Northeast Japan may have not played an major role in the later crustal evolution.

In Northeast Japan there are other supposed pre-Silurian basements, such as the Matsugadaira-Motai belt, the Unoki metamorphic rocks, and the Nishidohira gneiss; their isotopic ages are younger than geologically estimated presumably owing to later thermal events. Further geochronological study by whole-rock $\mathrm{Rb}-\mathrm{Sr}$ and U-Pb methods on these rocks, as well as on granitic clasts in the Siluro-Devonian formations, will give clearer evidence on age and nature of the older crust in Northeast Japan.

\section{ACKNOWLEDGMENTS}

The author wishes to thank Dr. T. NOZAWA, Mr. T. YoshidA, and Dr. M. KATADA of the Geological Survey of Japan for their continuous encouragement and cooperation, especially for help in collecting samples, discussion and review of the manuscript. Thanks are also due to Dr. S. ISHIHARA of the Geological Survey and Dr. S. KANISAWA of Tohoku University for supplying samples and valuable information.

\section{REFERENCES}

FAURE, G. and POWElL, J. L. (1972) Strontium isotope geology, Springer-Verlag.

Hashizume, M., Oike, K., Asano, S., Hamaguchi, H., O Kada, A., Murauchi, S., Shima, E. and NoGOSHI, M. (1968) Crustal structure in the profile across the northeastern part of Honshu, Japan, as derived from explosion seismic observations, Pt. 2, Crustal structure. Bull. Earthq. Res. Inst. 46, 607-630.

ISHII, K., SENDo, T., UEDA, Y. and Y AMASHITA, Y. (1960) Granitic rocks of the Hinokamiyama district, northeastern Kitakami massif. Sci. Rep. Tohoku Univ. Ser. III 6, 439-485.

ISHIZAKA, K. (1972) Rb-Sr dating of the igneous and metamorphic rocks of the Kurosegawa tectonic zone. J. Geol. Soc. Japan 78, 569-575 (in Japanese with English abstract).

ISHIZAKA, K. (1974) Geochronology of old rocks from the Japanese Islands-Specially on rocks from the Kurosegawa tectonic zone--. Abstract, 1974 Ann. Mtg. Geochem. Soc. Japan, 9-10 (in Japanese).

IUGS Subcommission (1973) Plutonic rocks-Classification and nomenclature recommended by 
the IUGS Subcommission on the systematics of igneous rocks. Geotimes 18, No.10, 26-30.

KaNo, H. (1954) Preliminary notes on tectonic relations between the granitic rocks and their country rocks in the Kitakami-central zone, Northeastern Japan (I) (Tectonic analysis of the granitic rocks). J. Geol. Soc. Japan 60, 241-254 (in Japanese with English abstract).

KANO, H. (1955) Preliminary notes on tectonic relations between the granitic rocks and their country rocks in the Kitakami-central zone (II). ibid. 61, 124-139 (in Japanese with English abstract).

KaWANO, Y. and UEDA, Y. (1964) K-A dating on the igneous rocks in Japan (I). Sci. Rep. Tohoku Univ. Ser. III 9, 99-122.

KAWANO, Y. and UEDA, Y. (1965) K-A dating on the igneous rocks in Japan (II)-Granitic rocks in Kitakami massif-. ibid. 9, 199-215.

KURASAWA, H. (1972) Isotopic composition of strontium in volcanic rocks from Towada volcano, northeast Japan. Bull. Volc. Soc. Japan 17, 158-159 (in Japanese).

MARUYAMA, T. (1972) Geochronology on granitic rocks distributed in the Gozaisho-Takanuki district, southern Abukuma mountains. Magma No.31, 9-13 (in Japanese).

MIKami, T. (1971) Preliminary notes of the Paleozoic sandstones from the Hikoroichi area, South Kitakami Mountains. Mem. Geol. Soc. Japan No.6, 33-37 (in Japanese with English abstract).

Minato, M., ChOI, D. R. and OKABE, Y. (1973a) New locality for the Silurian fossils in the Kitakami Mountains. J. Geol. Soc. Japan 79, 47 (in Japanese).

Minato, M., Hashimoto, S., Hunahashi, M., Ho, S., Choi, D. R. and Tazawa, J. (1973b) Higami granite and related faults. In Median Tectonic Line, ed. R. SUGIYAMA, Tokai Univ. Press, 263-270 (in Japanese with English abstract).

Murata, M., Kanisawa, S., Ueda, Y. and Takeda, N. (1974) Base of the Silurian system and the pre-Silurian granites in the Kitakami massif, Northeast Japan. J. Geol. Soc. Japan 80, 475-486 (in Japanese with English abstract).

NoHDA, S. (1973) Rb-Sr dating of the Yatsushiro granite and gneiss, Kyushu, Japan. Earth Planet. Sci. Lett. 20, 140-144.

Nozawa, T., Yoshida, T., KatadA, M. and Shibata, K. (1975) Intrusion of the Hikami granite into the Devonian system. Abstract, 1975 Ann. Mtg. Geol. Soc. Japan (in Japanese).

OKUBo, M. (1950) On the Gotlandian and Devonian deposits of Hikoroichi, Kesen-district, Iwate-Prefecture. J. Geol. Soc. Japan 56, 345-350 (in Japanese with English abstract).

ONUKI, Y. (1969) Geology of the Kitakami massif, Northeast Japan. Cont. Inst. Geol. Paleont. Tohoku Univ. No.69, 1-239 (in Japanese with English abstract).

SHIBATA, H. and OKADA, S. (1955) Chemical composition of Japanese granitic rocks in regard to petrographic provinces, Part 2. Sci. Rep. Tokyo Kyoiku Daigaku Sec.C 4, 141-161.

SHiBATA, K. (1973) K-Ar ages of the Hikami granite and the Usuginu granitic clasts. J. Geol. -Soc. Japan 79, 705-707 (in Japanese).

SHIBATA, K. and UCHIUMI, S. (1975) K-Ar ages of the Hikami granite, southern Kitakami mountains. Bull. Geol. Surv. J. (in press).

SHUTO, K. (1974) The strontium isotopic study of the Tertiary acid volcanic rocks from the southern part of Northeast Japan. Sci. Rep. Tokyo Kyoiku Daigaku Sec.C 12, 75-140.

SUZUKI, Y. (1952) On the structure of the granodioritic rocks in the Takata district of the Kitakami-mountainland. J. Geol. Soc. Japan 58, 1-16 (in Japanese with English abstract).

SUZUKI, Y.(1956) On the occurrence of the so-called Tsubonosawa gneiss in the Kitakami district, Japan. J. Fac. Sci. Hokkaido Univ. Ser.IV 9, 337-350. 
SUZUKI, Y. (1958) On the granitic rocks in the Kitakami mountain range. Jubilee Publ. Comm. Prof. J. SUZUKI Sixtieth Birthday, 316-324 (in Japanese with English abstract).

Watanabe, M. (1950) Igneous activities in the Kitakami mountainland. Mon. Assoc. Geol. Collab. No.4, 23p. (in Japanese).

YORK, D. (1966) Least-squares fitting of a straight line. Can. J. Phys. 44, 1079-1086. 